\title{
Revisiting the 'direct mineral cycling' hypothesis: arbuscular mycorrhizal fungi colonize leaf litter, but why?
}

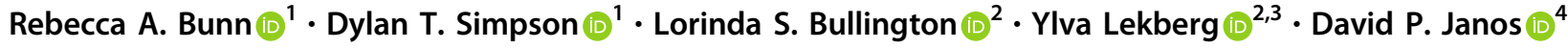

Received: 12 October 2018 / Revised: 8 February 2019 / Accepted: 1 March 2019 / Published online: 25 March 2019

(c) The Author(s) 2019. This article is published with open access

\section{A hypothesis of 'direct mineral cycling'}

Half a century ago in an Amazonian rainforest, Went and Stark [1, 2] observed 'endotrophic mycorrhizal' hyphae proliferating in leaf litter adjacent to mycorrhizal roots. They inferred the fungi were accessing, and subsequently transferring, litter-bound mineral nutrients to host plants in a phenomenon they called 'direct mineral cycling.' This hypothesis was consistent with acceptance of fungi as primary decomposers in forest ecosystems and mycorrhizal fungi as symbionts that transfer mineral nutrients (hereafter, 'nutrients') to host plants. 'Endotrophic mycorrhizas,' as used by those authors, were later termed 'arbuscular mycorrhizas' and involve a phylogenetically distinct group of fungi from the phylum Glomeromycota [3]. Early observations of arbuscular mycorrhizal (AM) fungi proliferating in organic matter led researchers to surmise saprotrophic capabilities [4-6]. However, attempts to culture AM fungi independent of host plants were unsuccessful, and researchers now understand AM fungi as obligate symbionts entirely dependent on host plant roots for carbon $[7,8]$. In fact, AM fungi appear incapable of producing the lytic enzymes necessary to cleave organic molecules $[9,10]$ and evidence still largely, but not universally, suggests these fungi are limited to assimilating inorganic forms of

Supplementary information The online version of this article (https:// doi.org/10.1038/s41396-019-0403-2) contains supplementary material, which is available to authorized users.

Rebecca A. Bunn

rebecca.bunn@wwu.edu

1 Department of Environmental Sciences, Western Washington University, 516 High St., MS-9181, Bellingham, WA 98225, USA

2 MPG Ranch, Missoula, MT, USA

3 Department of Ecosystem and Conservation Sciences, University of Montana, Missoula, MT, USA

4 Department of Biology, University of Miami, Miami, FL, USA nutrients (nitrogen reviewed by Hodge and Storer [11]; phosphorus by Smith et al. [12]). Thus, AM fungi alone are unlikely to access litter-bound nutrients as Went and Stark $[1,2]$ originally envisioned, and 'direct mineral cycling' has languished in the bin of unsupported hypotheses.

Yet AM fungi colonize litter in a variety of habitats (Table 1), and AM host plants are often successful in organic soils despite predictions that these plants are largely restricted to mineral soils where inorganic nutrients predominate [13, 14]. In this Perspective, we argue for a reconsideration of the 'direct mineral cycling' hypothesis; not because we believe that these fungi can directly mobilize organically bound nutrients, but because of ample evidence that AM fungi can influence degradation of organic matter and subsequently acquire and transfer a portion of released nutrients to their associated host plants $[15,16]$. Therefore, the functional consequences of AM fungi growing into leaf litter may match those of 'direct mineral cycling.' We review the literature and present new data that unequivocally show rapid colonization by AM fungi inside dead leaves in coniferous-dominated forests in the Pacific Northwest. Thus, we argue that AM fungal colonization of litter and not-yet-decomposed plant matter may be a global phenomenon that could have far-reaching implications for plant-plant interactions and nutrient cycling in both natural and managed ecosystems. Finally, we outline a set of questions that we hope will spur crossdisciplinary research into what we believe is an often overlooked and under-researched topic.

\section{Mycorrhizal fungi types in organic versus mineral soils: AM fungi defy the rules}

Initially, the 'direct mineral cycling' hypothesis was appealing because it explained an incongruity in tropical forests. Tropical forest soils are notoriously infertile due to leaching and phosphorus-sorption, yet they support abundant plant biomass. A closed nutrient cycle could explain how plant biomass is maintained despite low levels of 


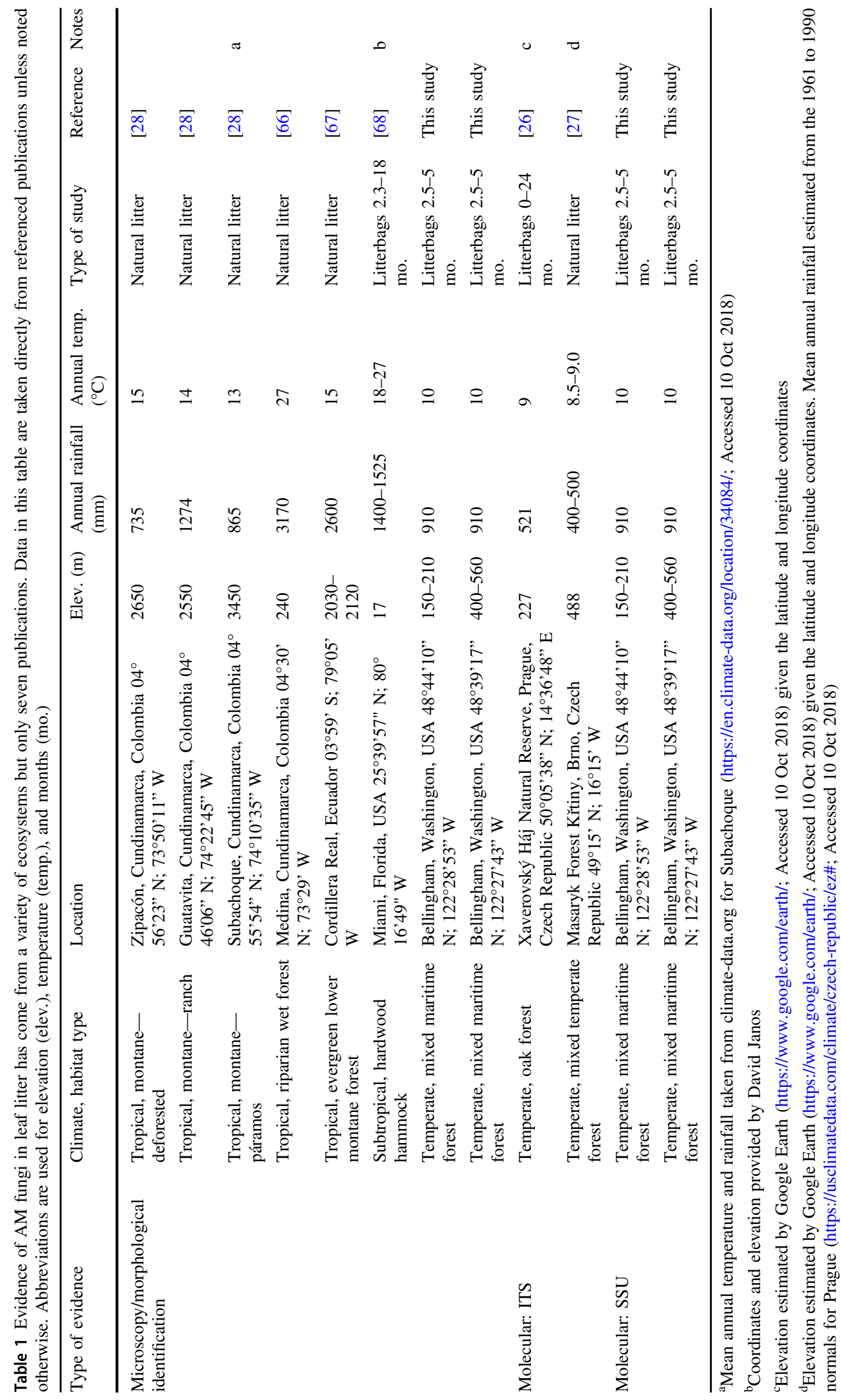


plant-available nutrients in soil. Although arbuscular mycorrhizas are known to improve host plant mineral nutrition in infertile soils, most nutrients in tropical systems are recycled from litter, and therefore, presumed to be initially inaccessible to AM fungi. Despite advances in mycorrhizal ecology, the success of AM hosts in tropical forests has remained a paradox.

In contrast to AM fungi, some ectomycorrhizal (EM) fungi seem capable of direct decomposition. EM fungi can produce lytic enzymes to release organically bound nutrients [17] and a growing body of evidence supports decomposer capabilities in some taxa [18]. This contrast suggests that EM, but not AM, fungi access organically bound nutrients. Read [13], and later Read and PerezMoreno [14], proposed that this functional difference between mycorrhizal types explains the global distribution of their host plants. Under this framework, the abundance of AM fungi would be inversely related to concentrations of soil organic matter (SOM) and soil fertility would delineate the occurrence of AM plant species. If true, AM hosts should predominate at mid to low latitudes and low elevations where rapid decomposition results in thin litter layers and low SOM concentrations. Yet, AM hosts are prevalent throughout northern and central latitudes in Europe [19], and a global survey failed to find any correlation between SOM and abundance of AM fungi [20]. Further, AM fungi and their plant hosts can be widespread in SOM-rich ecosystems, including alpine meadows [21], tropical cloud forests [22], and the Arctic [23]. Although AM fungal community composition may shift with SOM at a global level [24] if not a landscape level [25], AM fungi and their hosts clearly are not restricted to mineral soils.

\section{AM fungi colonize leaf litter and recently fallen leaves across ecological regions}

Proliferation of AM fungi in leaf litter (Table 1), well above the mineral soil horizon, further contradicts the predictions of Read [13] and Read and Perez-Moreno [14]. Evidence of this phenomenon has recently become even more compelling with molecular data indicating the presence of Glomeromycotan fungi in leaf litter in temperate forests (this study; [26, 27]). Not only do AM fungi occur in the litter horizon, they also may colonize plant leaves that have not yet substantially decomposed [28].

In this Perspective, we add to previous work and unequivocally show rapid AM fungal colonization of dead leaves in mixed maritime forests dominated by the EM host, Douglas fir (Pseudotsuga menziesii; Fig. 1a, Supporting Information Table S1). We combined the inherent strengths of molecular (targeting the small subunit ribosomal RNA [rRNA] gene) and microscopic techniques. Microscopic observations can reveal spatial relationships and a measure of abundance, and molecular data can provide indisputable evidence that the observed fungi truly are Glomeromycotan. Using litterbags with newly fallen leaves (Fig S1) and cleaning leaf surfaces prior to molecular assessments of AM fungi using the AM fungi-specific primer pair WANDAAML2 (Table S2), we observed AM fungus-like hyphae growing inside intact leaf litter within 3 months of litter bag deployment (Fig. 1b). Hyphal densities (based on morphological features) in leaf litter correlated with total sequence abundances of AM fungi in soil $\left(r=0.81, t_{6}=\right.$ $3.4, p=0.015$; Fig S2). Concordantly, total sequence abundances of AM fungi in leaf litter correlated with those in soil $\left(\ln [x+1]\right.$ transformed; $r=0.76, t_{6}=2.8, p=0.030$; Fig S3). This is logical given our understanding that the obligately root-associated fungi would extend between roots in the soil and leaf litter, and implies that AM fungi enter leaf litter near AM host plants. In addition, we found substantial variation in the number of $\mathrm{AM}$ fungal sequences in leaf litter among sites, which may reflect a patchy distribution of AM host plants in these forests. Dominant AM fungi virtual taxa (VT) assemblages in soil were distinct from those in leaf litter (Fig. 1c, Tables S3 and S4 Fig S4). However, VT detected only in leaf litter did not cluster phylogenetically, but instead were closely related and sometimes identical to VT detected only in soil (Fig. S5). This suggests niche differentiation similar to what has been found with EM fungi [29] and fungi in general [27], but differentiation may occur within, rather than among, phylogenetic clusters. Importantly, our results show that AM fungi may enter leaf litter even in forests dominated by EM host plants.

Our data corroborate and strengthen previous findings that AM fungi colonize leaf litter across a wide array of ecological and climatic regions. Furthermore, AM fungi appear to penetrate new litter within a few months and AM fungal taxa may differ in their preference for leaves or soil. Our methods and full results can be found in Supplemental Information.

\section{What stimulates AM fungi to colonize leaf litter?}

Perhaps we should not be surprised if AM fungi frequently colonize leaf litter. Although AM fungal hyphae typically grow through the soil matrix and in the cortical tissue of plant roots, they also have been observed within other substrates. AM fungal hyphae and vesicles have been found in plant parts other than root cortical tissues, i.e., root xylems and rhizome scales [30, 31], and AM fungal spores have been found within oribatid mites, dead seeds, and even other spores [32-35]. The propensity of AM fungi to grow into 'tiny holes' has long been inferred from their successful exploitation of such nutrient-rich soil microsites, and that attribute alone might explain the presence of AM fungi in 


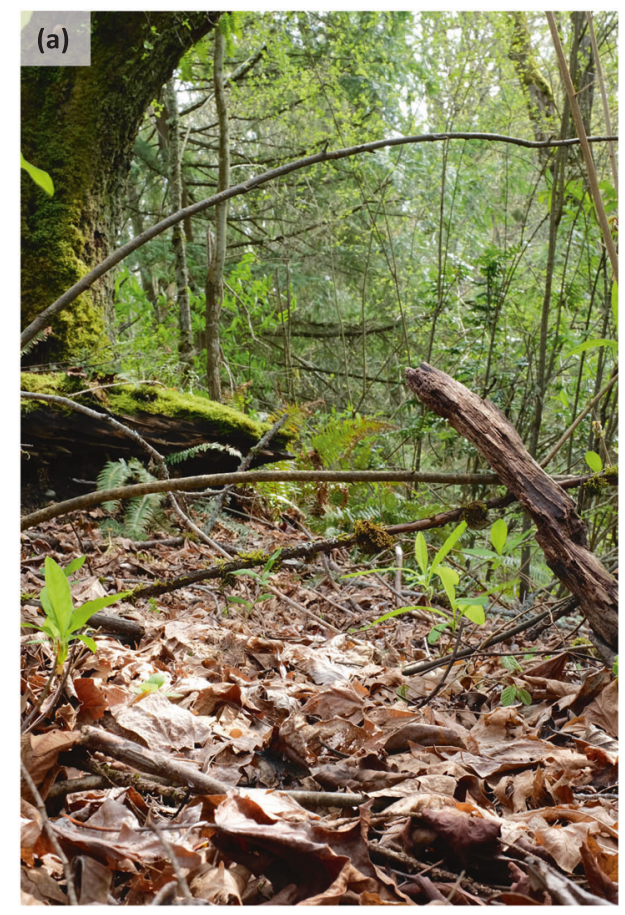

Fig. 1 a Bigleaf maple (Acer macrophyllum) litter (foreground) on the floor of a temperate, North American, Pacific Northwest forest. Indian plum (Oemleria cerasiformis) and sword fern (Polystichum munitum) grow up through the litter. These leaves may have fallen from the mature bigleaf maple tree (seen here as a moss-covered, large trunk on the left), but bigleaf maple litter is also found in stands with the dominant overstory tree, ectomycorrhizal Douglas fir (Pseudotsuga menziesii; dark horizontal branches of Douglas fir are shown just to the right of the bigleaf maple trunk). b Arbuscular mycorrhizal (AM) fungus-like spore with associated hyphae as well as other fungus

these unusual substrates. However, these substrates all are 'high quality' organic materials (i.e., have low carbon to nitrogen ratios). Conventional views on AM fungi would predict fungal growth occurring after decomposition of the substrate has begun and at least some mineralization has occurred. However, our observation of active colonization of new leaf litter implies AM fungi instead might 'recognize' substrates as a source of nutrients prior to decomposition.

AM fungi responding to litter-bound nutrients may have been considered unlikely at one time, but this is changing. Although AM fungi are best known for scavenging inorganic phosphorus from the soil, they also can access organically bound phosphorus when grown with other soil biota [36], particularly in phosphorus-limited environments [37]. Furthermore, when nitrogen is limiting, AM fungi can sense and upregulate genes in response to organic nitrogen [38]. In fact, attraction to nitrogen may underlie the contrast between the typical positive growth response of AM fungi to high quality organic matter amendments (e.g., organic soil particles [8]; cattle manure [39]; and broadleaf litter $[40,41])$ versus a neutral to negative response to low-

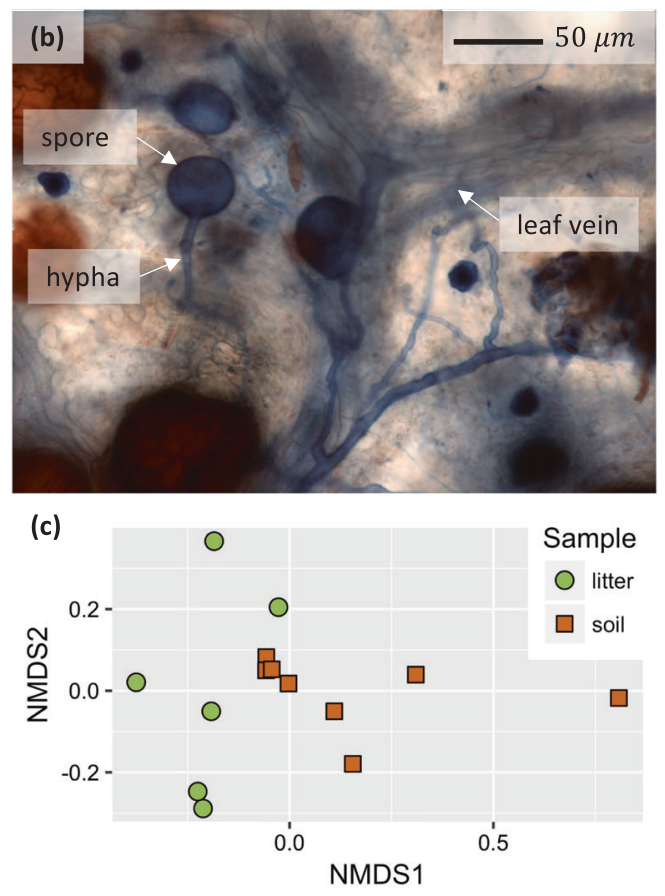

hyphae in bigleaf maple litter. Leaf veins also are visible. Litter was cleared and stained with Trypan blue and then viewed with light microscopy at $400 \times$. c Nonmetric multidimensional ordination of predominant arbuscular mycorrhizal fungi amplified from leaf litter and adjacent soil samples. Fungal communities amplified from litter and soil were distinct from each other $(p=0.004$, Table S4). SSU sequence data were resampled to 114 sequences/sample. Samples with fewer sequences were dropped from this analysis. Full dataset (prerarefaction) is available in Table $\mathrm{S} 2$

quality amendments (e.g., cellulose [42-44]; but see [45, 46]). In some instances, AM fungi may find organically bound nutrients in litter even more accessible than inorganic forms in the underlying soil [47]. Thus, colonization of litter by AM fungi may occur when litter is rich in nutrients that are otherwise scarce in the soil matrix, even if those nutrients are organically bound.

\section{How can AM fungi access nutrients in leaf litter?}

In the absence of other soil biota, AM fungi are unable to mobilize or access organically bound nutrients (i.e., under gnotobiotic conditions [48]; but see [49]). However, in the presence of other soil biota, AM fungi can accelerate decomposition of complex organic materials like grass litter $[15,50]$. Thus, the effects of AM fungi on decomposition must be mediated through other organisms. In fact, experimental systems that have demonstrated transport of nutrients from organic matter to host plants via AM fungi typically include the methodological step of equalizing initial microbial communities across the mycorrhizal and nonmycorrhizal treatments (e.g., [15, 16, 51]). Consequently, 
this nutrient pathway most likely results from an interaction between AM fungi and the microbial community, rather than the fungi alone. In such interactions, AM fungi may release labile carbon into their hyphosphere, stimulating activity of microbial decomposers [52] and increasing degradation rates of SOM [53, 54] in a version of priming effects [55]. The involved microbes might be specialized, living primarily on hypha surfaces and forming a kind of secondary symbiosis with mycorrhizal fungi in which access to organically bound nutrients is traded for mycorrhizal carbon (i.e., 'hypersymbionts,' [56]). Alternatively, the microbes could be freeliving organisms, which respond to any labile carbon source. Researchers are just beginning to untangle pathways from organically bound nutrients to AM fungi and to identify the involved organisms. For instance, while investigating pathways of nitrogen, Bukovská et al. [44] found a correlation between hyphal proliferation and prokaryotic ammonium oxidizer abundance, suggesting ammonium-oxidizers may control the availability of nitrogen to AM fungi. Yet, by including a non-mycorrhizal control in a subsequent study, Bukovská et al. [57] observed that ammonium oxidizers were actually repressed by AM fungi, and instead, eukaryotic protists appeared to be the important players in nitrogen recycling. Pathways for phosphorus, which include mutually beneficial interactions between AM fungi and phosphate-solubilizing bacteria [58], may be less complicated. In phosphorus-limited environments, AM fungi and free-living phosphate-solubilizing bacteria benefit each other by providing the essential carbon or phosphorus that the other needs [59], which can increase mineralization of organically bound phosphorus [60].

No matter the pathway, an active role of AM fungi in stimulating decomposition implies a tight coupling between AM fungi and decomposers, groups that have historically been considered separate.

\section{Consequences of AM fungi colonizing leaf litter and future research directions}

Based on these cumulative research findings, we propose that Went and Stark's [1,2] hypothesis may be accurate regarding the net effects of AM fungal colonization of leaf litter despite a misunderstanding of the underlying mechanisms. If AM fungi really are cued to colonize leaf litter because the litter is a nutrient source, and subsequently promote decomposition through stimulation of other organisms, then colonization of leaf litter may be an important pathway for cycling nutrients from litter to host plant. This is the essence of the 'direct mineral cycling' hypothesis. If true, then this nutrient pathway bypasses the soil matrix and allows AM hosts to be successful in infertile soils, potentially explaining the tropical forests paradox. Furthermore, if AM hosts have access to organically bound nutrients, they may be more competitive with EM hosts in organic soils than previously recognized. Yet, the extent to which $\mathrm{AM}$ hosts have access to nitrogen acquired by AM fungi varies widely for reasons that are not yet understood [11]. Thus, the significance of this pathway requires further investigation. Nevertheless, by assimilating nutrients before they reach the soil matrix AM fungi likely increase overall nutrient retention within ecosystems. Indeed, AM fungi are known to dramatically decrease leaching losses of inorganic phosphorus [61] and nitrogen [62, 63]. Recent evidence suggests the same may also be true for organically bound nutrients [64], which may partially occur through AM fungal colonization of leaf litter.

Many aspects of these ideas are preliminary. We do not yet have comprehensive data about the geographic extent of the phenomenon of AM fungi in leaf litter or the abundance of AM fungi relative to fungal decomposers in leaf litter, nor do we understand the biotic and abiotic factors that affect such colonization. We do not know if AM fungi are frequently coupled with decomposers, or if the studies cited here are isolated cases. Quantifying the abundance of AM fungi in leaf litter using either quantitative PCR or neutral lipid fatty-acid analyses through time might begin to address such questions. We have yet to determine if nutrients immediately acquired from litter and transferred to host plants are of sufficient quantity to affect plant fitness. Moreover, many of the studies cited here (e.g., [15, 41, 43, $57,59])$ are based on only one or two AM fungal taxa. This is a serious handicap because the functional differences among AM fungi are not well understood [65] and community effects are difficult to predict from single taxon studies. Yet, all these limitations are open doors for future research. We present questions that we consider most pressing (Table 2), but additional lines of inquiry could be formulated. We believe full answers to these questions will be possible only with cooperation across a wide range of scientific skill sets. For instance, on a molecular level, biochemists and microbiologists are needed to identify the pathways by which nutrients may move from bound in leaf litter to being assimilated into the mycorrhizal symbiosis; biogeochemists are needed to quantify the relative magnitude of nutrients potentially cycled through this pathway; and on an organismal to landscape level, plant and soil ecologists are needed to determine if this nutrient pathway is significant for individual plants and if it helps explain the competitive success of AM hosts in forest ecosystems.

\section{Conclusions}

We corroborate and extend findings of AM fungi colonizing leaf litter across climatic regions. In addition, we find different AM fungal taxa predominated within leaf litter and 
Table 2 Questions that need to be investigated to further understand the nutrient cycling in ecosystems, as well as plant distributions in specific ecosystems

\begin{tabular}{ll}
\hline Item no. & Questions \\
\hline 1 & $\begin{array}{l}\text { Is colonization of litter by arbuscular mycorrhizal (AM) fungi a global phenomenon that occurs across ecosystems that contain AM } \\
\text { host plants? } \\
2\end{array}$ \\
$\begin{array}{l}\text { In colonizing litter, do AM fungi minimize leaching losses of mineral nutrients in ecosystems with relatively rapid decomposition, } \\
\text { such as lowland tropical forests on Oxisols and Ultisols? }\end{array}$ \\
$\begin{array}{l}\text { Do AM fungi accelerate decomposition rates through multiple pathways including stimulation of microbial decomposers? } \\
\text { Do AM fungal taxa differ in their propensity to colonize organic matter? If so, are those differences related to their ability to recognize } \\
\text { organic sources of nutrients and/or to promote decomposition? } \\
\text { Given evidence of AM fungi accelerating decomposition rates and transporting mineral nutrients from organic substrates to host plants, } \\
\text { could we expect AM host plants to be competitive across both organic and mineral soils, including oligotrophic ecosystems with slow } \\
\text { decomposition and accumulation of organic matter, and mixed-mycorrhiza forests, such as those of the Pacific Northwestern United } \\
\text { States? }\end{array}$
\end{tabular}

soil, suggesting that those fungi may differ in their tendency to colonize leaf litter, which could result in niche differentiation between substrates. Taking our findings together with previous work on AM fungi and organic substrates, we suggest that mycorrhiza research may be missing a large and important part of AM fungal function. Although root colonization by AM fungi and extraradical hyphal density in mineral soil are frequently quantified, all too rarely has the spread of AM fungal hyphae within litter been investigated. Such spread may be a 'hidden' indication of the importance of AM fungi in forest ecosystems where their functions may include promoting the release of nutrients from leaf litter and transferring nutrients to host plants, thereby retaining nutrient capital. If true, AM fungi are providing host plants access to nutrient pools hitherto thought to be limited to hosts of other types of mycorrhizal fungi, which may help explain the success of AM host plants in both organic and tropical soils.

Acknowledgements We thank Karianna Clausen, Faythe Duran, Regina O'Kelley, and Brandon Osterlund for lab and field assistance; and Maarja Öpik and Siim-Kaarel Sepp for consulting on VT assignments. Sehome Arboretum Board provided site access. WWU RSP funded materials via an Undergraduate Research and Creative Opportunities Grant and open-access publication via a Discretionary Grant. LSB and YL are grateful to MPG Ranch for funding. Sequencing was performed by the IBEST Genomics Resources Core at the University of Idaho and was supported in part by NIH COBRE grant P30GM103324. We thank Peter Kennedy for a helpful conversation on the role of EM fungi in decomposition. An earlier version of this manuscript was improved by comments from anonymous reviewers, and from Miranda Hart, John Klironomos, Maarja Öpik, and Cathy Zabinski.

\section{Compliance with ethical standards}

Conflict of interest The authors declare that they have no conflict of interest.

Publisher's note: Springer Nature remains neutral with regard to jurisdictional claims in published maps and institutional affiliations.
Open Access This article is licensed under a Creative Commons Attribution 4.0 International License, which permits use, sharing, adaptation, distribution and reproduction in any medium or format, as long as you give appropriate credit to the original author(s) and the source, provide a link to the Creative Commons license, and indicate if changes were made. The images or other third party material in this article are included in the article's Creative Commons license, unless indicated otherwise in a credit line to the material. If material is not included in the article's Creative Commons license and your intended use is not permitted by statutory regulation or exceeds the permitted use, you will need to obtain permission directly from the copyright holder. To view a copy of this license, visit http://creativecommons. org/licenses/by/4.0/.

\section{References}

1. Went FW, Stark N. The biological and mechanical role of soil fungi. Pro Natl Acad Sci USA 1968;60:497-504. https://doi.org/ 10.1126/science. 160.3826 .444

2. Went FW, Stark N. Mycorrhiza. Bioscience. 1968;18:1035-9.

3. Tedersoo L, Sánchez-Ramírez S, Kõljalg U, Bahram M, Döring M, Schigel D, et al. High-level classification of the Fungi and a tool for evolutionary ecological analyses. Fungal Divers. 2018;90:135-59. https://doi.org/10.1007/s13225-018-0401-0

4. Hepper CM, Warner A. Role of organic matter in growth of a vesicular-arbuscular mycorrhizal fungus in soil. Trans Br Mycol Soc. 1983;81:155-6. https://doi.org/10.1016/S0007-1536(83)80219-8

5. Mosse B. Observations on the extra-matrical mycelium of a vesicular-arbsucular endophyte. Trans $\mathrm{Br}$ Mycol Soc. 1959;42:439-48.

6. Nicolson TH. Mycorrhiza in the Gramineae. Trans Br Mycol Soc. 1959;42:421-38. https://doi.org/10.1016/S0007-1536(60)80017-4

7. Smith SE, Read D. Mycorrhizal symbiosis. 3rd edn. London: Elsevier Science; 2008. http://books.google.com/books? $\mathrm{id}=\mathrm{qLciOJaG0C} 4 \mathrm{C}$

8. St. John TV, Coleman DC, Reid CPP. Association of vesiculararbuscular mycorrhizal hyphae with soil organic particles. Ecology. 1983;64:957-9.

9. Tisserant E, Kohler A, Dozolme-Seddas P, Balestrini R, Benabdellah K, Colard A, et al. The transcriptome of the arbuscular mycorrhizal fungus Glomus intraradices (DAOM 197198) reveals functional tradeoffs in an obligate symbiont. New Phytol. 2012;193:755-69. https://doi.org/10.1111/j.1469-8137.2011. 03948.x

10. Tisserant E, Malbreil M, Kuo A, Kohler A, Symeonidi A, Balestrini R, et al. Genome of an arbuscular mycorrhizal fungus 
provides insight into the oldest plant symbiosis. Proc Natl Acad Sci USA 2013;110: 20117-22. https://doi.org/10.1073/pnas. 1313452110

11. Hodge A, Storer K. Arbuscular mycorrhiza and nitrogen: Implications for individual plants through to ecosystems. Plant Soil. 2015;386:1-19. https://doi.org/10.1007/s11104-014-2162-1

12. Smith SE, Anderson IC, Smith, FA. Mycorrhizal associations and phosphorus acquisition: from cells to ecosystems. Annual Plant Rev 2015;48:409-39. https://doi.org/10.1002/9781118958841. ch14

13. Read D. Mycorrhizas in ecosystems. Experientia. 1991;47:37691. https://doi.org/10.1007/BF01972080

14. Read D, Perez-Moreno J. Mycorrhizas and nutrient cycling in ecosystems - a journey towards relevance? New Phytol. 2003; 157:475-92. https://doi.org/10.1046/j.1469-8137.2003.00704.x

15. Hodge A, Campbell CD, Fitter AH. An arbuscular mycorrhizal fungus accelerates decomposition and acquires nitrogen directly from organic material. Nature. 2001;413:297-9. https://doi.org/10. $1038 / 35095041$

16. Leigh J, Hodge A, Fitter AH. Arbuscular mycorrhizal fungi can transfer substantial amounts of nitrogen to their host plant from organic material. New Phytol. 2009;181:199-207. https://doi.org/ 10.1111/j.1469-8137.2008.02630.x

17. Kohler A, Kuo A, Nagy LG, Morin E, Barry KW, Buscot F, et al. Convergent losses of decay mechanisms and rapid turnover of symbiosis genes in mycorrhizal mutualists. Nat Genet. 2015;47:410-5. 10.1038/ng

18. Lindahl BD, Tunlid A. Ectomycorrhizal fungi - potential organic matter decomposers, yet not saprotrophs. New Phytol. 2015;205:1443-7. https://doi.org/10.1111/nph.13201

19. Bueno CG, Moora M, Gerz M, Davison J, Öpik M, Pärtel M, et al. Plant mycorrhizal status, but not type, shifts with latitude and elevation in Europe. Glob Ecol Biogeogr. 2017;26:690 https://doi. org/10.1111/geb.12582

20. Treseder KK, Cross A. Global distributions of arbuscular mycorrhizal fungi. Ecosystems. 2006;9:305-16. https://doi.org/ 10.1007/s10021-005-0110-x

21. Read DJ, Haselwanter K. Observation on the mycorrhizal status of some alpine plant communities. New Phytol. 1981;88:341-52.

22. Kottke I, Beck A, Oberwinkler F, Homeier J, Neill D. Arbuscular endomycorrhizas are dominant in the organic soil of a neotropical montane cloud forest. J Trop Ecol. 2004;20:125-9.

23. Newsham KK, Eidesen PB, Davey ML, Axelsen J, Courtecuisse E, Flintrop $\mathrm{C}$, et al. Arbuscular mycorrhizas are present on Spitsbergen. Mycorrhiza. 2017;27:725-31. https://doi.org/10. 1007/s00572-017-0785-9

24. Davison J, Moora M, Öpik M, Adholeya A, Ainsaar L, Bâ A, et al. Global assessment of arbuscular mycorrhizal fungus diversity reveals very low endemism. Science. 2015;349:970-3. https:// doi.org/10.5061/dryad. $2 \mathrm{~m} 15 \mathrm{n}$

25. Hazard C, Gosling P, van der Gast CJ, Mitchell DT, Doohan FM, Bending GD. The role of local environment and geographical distance in determining community composition of arbuscular mycorrhizal fungi at the landscape scale. ISME. 2013;7:498-508. https://doi.org/10.1038/ismej.2012.127

26. Voříšková J, Baldrian P. Fungal community on decomposing leaf litter undergoes rapid successional changes. ISME J. 2013;7:47786. https://doi.org/10.1038/ismej.2012.116

27. Bahnmann B, Mašínová X, Halvorsen R, Davey ML, Sedlák P, et al. Effects of oak, beech and spruce on the distribution and community structure of fungi in litter and soils across a temperate forest. Soil Biol Biochem. 2018;119:162-73.

28. Aristizábal C, Rivera E-L, Janos DP. Arbuscular mycorrhizal fungi colonize decomposing leaves of Myrica parvifolia, M. pubescens and Paepalanthus sp. Mycorrhiza. 2004;14:221-8. https://doi.org/10.1007/s00572-003-0259-0
29. Dickie IA, Xu B, Koide RT. Vertical niche differentiation of ectomycorrhizal hyphae in soil as shown by T-RFLP analysis. New Phytol. 2002;156:527-35.

30. Taber RA, Strong ME. Vesicular-arbuscular mycorrhiza in roots and xylem of Tradescantia. Mycologia. 1982;74:152.

31. Taber RA, Trappe JM. Vesicular-arbuscular mycorrhiza in rhizomes, scale-like leaves, roots, and xylem of ginger. Mycologia. 1982;74:156 https://doi.org/10.2307/3792644

32. Koske RE. Spores of VAM fungi inside spores of VAM fungi. Mycologia. 1984;76:853.

33. Rabatin SC, Rhodes LH. Acaulospora bireticulata inside Oribatid Mites. Mycologia. 1982;74:859 https://doi.org/10.2307/3792878

34. Taber RA. Occurrence of Glomus spores in weed seeds in soil. Mycologia. 1982;74:515 https://doi.org/10.2307/3792978

35. Taber RA. Gigaspora spores and associated hyperparasites in weed seeds in soil. Mycologia. 1982;74:1026-31.

36. Wang X-X, Hoffland E, Feng G, Kuyper TW. Phosphate uptake from phytate due to hyphae-mediated phytase activity by arbuscular mycorrhizal maize. Front Plant Sci. 2017;8:1-8. https://doi. org/10.3389/fpls.2017.00684

37. Xu J, Liu S, Song S, Guo H, Tang J, Yong JWH, et al. Arbuscular mycorrhizal fungi influence decomposition and the associated soil microbial community under different soil phosphorus availability. Soil Biol Biochem. 2018;120:181-90. https://doi.org/10.1016/j. soilbio.2018.02.010

38. Cappellazzo G, Lanfranco L, Bonfante P. A limiting source of organic nitrogen induces specific transcriptional responses in the extraradical structures of the endomycorrhizal fungus Glomus intraradices. Curr Genet. 2007;51:59-70. https://doi.org/10.1007/ s00294-006-0101-2

39. Gryndler M, Larsen J, Hršelová H, Řezáčová V, Gryndlerová H, Kubát J. Organic and mineral fertilization, respectively, increase and decrease the development of external mycelium of arbuscular mycorrhizal fungi in a long-term field experiment. Mycorrhiza. 2006;16:159-66. https://doi.org/10.1007/s00572-005-0027-4

40. Albertsen A, Ravnskov S, Green H, Jensen DF, Larsen J. Interactions between the external mycelium of the mycorrhizal fungus Glomus intraradices and other soil microorganisms as affected by organic matter. Soil Biol Biochem. 2006;38:1008-14. https://doi. org/10.1016/J.SOILBIO.2005.08.015

41. Saia S, BenÍtez E, Garcĺa-Garrido JM, Settanni L, Amato G, Giambalvo D. The effect of arbuscular mycorrhizal fungi on total plant nitrogen uptake and nitrogen recovery from soil organic material. J Agric Sci. 2014;152:370-8. https://doi.org/10.1017/ S002185961300004X

42. Avio L, Giovannetti M. Vesicular-arbuscular mycorrhizal infection of lucerne roots in a cellulose-amended soil. Plant Soil. 1988;112:99-104.

43. Ravnskov S, Larsen J, Olsson PA, Jakobsen I. Effects of various organic compounds on growth and phosphorus uptake of an arbuscular mycorrhizal fungus. New Phytol. 1999;141:517-24.

44. Bukovská P, Gryndler M, Gryndlerová H, Püschel D, Jansa J. Organic nitrogen-driven stimulation of arbuscular mycorrhizal fungal hyphae correlates with abundance of ammonia oxidizers. Front Microbiol. 2016;7:1-15. https://doi.org/10.3389/fmicb. 2016.00711

45. Joner EJ, Jakobsen I. Growth and extracellular phosphatase activity of arbuscular mycorrhizal hyphae as influenced by soil organic matter. Soil Biol Biochem. 1995;27:1153-9. https://doi. org/10.1016/0038-0717(95)00047-I

46. Gryndler M, Vosátka M, Hršelová H, Chvátalová I, Jansa J. Interaction between arbuscular mycorrhizal fungi and cellulose in growth substrate. Appl Soil Ecol. 2002;19:279-88. https://doi.org/ 10.1016/S0929-1393(02)00004-5

47. Sheldrake M, Rosenstock NP, Revillini D, Olsson PA, Mangan S, Sayer EJ, et al. Arbuscular mycorrhizal fungal community 
composition is altered by long-term litter removal but not litter addition in a lowland tropical forest. New Phytol. 2017;214:45567. https://doi.org/10.1111/nph.14384

48. Leigh J, Fitter AH, Hodge A. Growth and symbiotic effectiveness of an arbuscular mycorrhizal fungus in organic matter in competition with soil bacteria. FEMS Microbiol Ecol. 2011;76:428-38. https://doi.org/10.1111/j.1574-6941.2011.01066.x

49. Koide RT, Kabir Z. Extraradical hyphae of the mycorrhizal fungus Glomus intraradices can hydrolyse organic phosphate. New Phytol. 2000;148:511-17. https://doi.org/10.1046/j.1469-8137. 2000.00776.x

50. Cheng L, Booker FL, Tu C, Burkey KO, Zhou L, Shew HD, et al. Arbuscular mycorrhizal fungi increase organic carbon decomposition under elevated $\mathrm{CO}_{2}$. Science. 2012;337:1084-7. https:// doi.org/10.1126/science. 1224304

51. Hodge A, Fitter AH. Substantial nitrogen acquisition by arbuscular mycorrhizal fungi from organic material has implications for N cycling. Proc Natl Acad Sci USA 2010;107: 13754-59.

52. Herman DJ, Firestone MK, Nuccio EE, Hodge A. Interactions between an arbuscular mycorrhizal fungus and a soil microbial community mediating litter decomposition. FEMS Microbiol Ecol. 2012;80:236-47. https://doi.org/10.1111/j.1574-6941.2011. 01292.x

53. Paterson E, Sim A, Davidson J, Daniell TJ. Arbuscular mycorrhizal hyphae promote priming of native soil organic matter mineralisation. Plant Soil. 2016;408:243-54. https://doi.org/10. 1007/s11104-016-2928-8

54. Talbot JM, Allison SD, Treseder KK. Decomposers in disguise: mycorrhizal fungi as regulators of soil $\mathrm{C}$ dynamics in ecosystems under global change. Funct Ecol. 2008;22:955-63. https://doi.org/ 10.1111/j.1365-2435.2008.01402.x

55. Kuzyakov Y. Priming effects: interactions between living and dead organic matter. Soil Biol Biochem. 2010;42:1363-71. https://doi.org/10.1016/J.SOILBIO.2010.04.003

56. Jansa J, Bukovská P, Gryndler M. Mycorrhizal hyphae as ecological niche for highly specialized hypersymbionts - or just soil free-riders? Front Plant Sci. 2013;4:1-8. https://doi.org/10.3389/ fpls.2013.00134

57. Bukovská P, Bonkowski M, Konvalinková T, Beskid O, Hujslová $\mathrm{M}$, Püschel D, et al. Utilization of organic nitrogen by arbuscular mycorrhizal fungi - is there a specific role for protists and ammonia oxidizers? Mycorrhiza. 2018;28:269-83. https://doi.org/ 10.1007/s00572-018-0825-0
58. Ordoñez YM, Fernandez BR, Lara LS, Rodriguez A, Uribe-Vielez D, Sanders IR. Bacteria with phosphate solubilizing capacity alter mycorrhizal fungal growth both inside and outside the root and in the presence of native microbial communities. PLoS ONE. 2016;11:1-18. https://doi.org/10.1371/journal.pone.0154438

59. Zhang L, Xu M, Liu Y, Zhang F, Hodge A, Feng G. Carbon and phosphorus exchange may enable cooperation between an arbuscular mycorrhizal fungus and a phosphate-solubilizing bacterium. New Phytol. 2016;210:1022-32. https://doi.org/10.1111/nph. 13838

60. Zhang L, Fan J, Ding X, He X, Zhang F, Feng G. Hyphosphere interactions between an arbuscular mycorrhizal fungus and a phosphate solubilizing bacterium promote phytate mineralization in soil. Soil Biol Biochem. 2014;74:177-83. https://doi.org/10. 1016/j.soilbio.2014.03.004

61. Asghari HR, Chittleborough DJ, Smith FA, Smith SE. Influence of arbuscular mycorrhizal (AM) symbiosis on phosphorus leaching through soil cores. Plant Soil. 2005;275:181-93. https://doi. org/10.1007/s11104-005-1328-2

62. van der Heijden MGA. Mycorrhizal fungi reduce nutrient loss from model grassland ecosystems. Ecology. 2010;91:1163-71. https://doi.org/10.1890/09-0336.1

63. Asghari HR, Cavagnaro TR. Arbuscular mycorrhizas reduce nitrogen loss via leaching. PLoS ONE. 2012;7:3-7. https://doi. org/10.1371/journal.pone.0029825

64. Bender SF, Conen F, van der Heijden MGA. Mycorrhizal effects on nutrient cycling, nutrient leaching and $\mathrm{N}_{2} \mathrm{O}$ production in experimental grassland. Soil Biol Biochem. 2015;80:283-92. https://doi.org/10.1016/J.SOILBIO.2014.10.016

65. Powell, JR, Rillig MC. Biodiversity of arbuscular mycorrhizal fungi and ecosystem function. New Phytologist. 2018. https://doi. org/10.1111/nph.15119

66. Posada RH, Madriñan S, Rivera E-L. Relationships between the litter colonization by saprotrophic and arbuscular mycorrhizal fungi with depth in a tropical forest. Fungal Biol. 2012;116:74755. https://doi.org/10.1016/j.funbio.2012.04.003

67. Camenzind T, Rillig MC. Extraradical arbuscular mycorrhizal fungal hyphae in an organic tropical montane forest soil. Soil Biol Biochem. 2013;64:96-102. https://doi.org/10.1016/j.soilbio.2013. 04.011

68. Aristizábal C. Arbuscular mycorrhizal fungi enhance the acquisition of mineral nutrients from leaf litter by Morella cerifera. Miami, Florida: University of Miami; 2008. PhD thesis 